\title{
Article
}

Mycosphere

\section{Trichaptum (Basidiomycota) in tropical America: a sequence study}

\author{
Vlasák $\mathbf{J}^{1 *}$ and Vlasák J Jr. ${ }^{2}$
}

\author{
${ }^{1}$ Biology Centre of the Academy of Sciences of the Czech Republic, Branišovská 31, CZ-370 05 České Budějovice, \\ Czech Republic \\ ${ }^{2} 207$ Silverbrook Dr., Schwenksville, PA, USA
}

Vlasák J, Vlasák J Jr 2017 - Trichaptum (Basidiomycota) in tropical America: a sequence study. Mycosphere 8(6), 1217-1227, Doi 10.5943/mycosphere/8/6/8

\begin{abstract}
A comprehensive study on Trichaptum was performed on the basis of collections from Europe, USA and Central America. The phylogenetic analysis, including 33 newly generated nuc rDNA ITS sequences revealed four new lineages. Combined with morphological evidence, three new lineages are described and illustrated as new species: Trichaptum agricola, T. confertum and T. resacarium; one new lineage represented by a single collection is treated as unidentified taxon. Nigrofomes melanoporus ITS sequence is shown to merge into the Trichaptum clade.
\end{abstract}

Key words - Hymenochaetales - taxonomy - Costa Rica

\section{Introduction}

The genus Trichaptum Murrill 1904 contains mostly pileate polypores with tomentose to hirsute upper surface, blackish-brown, gray, dirty white and more or less purplish on growing tubes, a dimitic/trimitic hyphal system, mostly apically encrusted cystidia, hyaline, thin-walled, mostly cylindric basidiospores, and causing a white rot (Gilbertson \& Ryvarden 1987). Because of tough tissue and trametoid appearance, many species were treated in Trametes Fr. 1836 (e.g. Pilát 1936) until Donk (1933) established genus Hirschioporus Donk for temperate zone species. Ryvarden \& Johansen (1980) concluded that Hirschioporus spp. were not essentially different from tropical species with more fleshy and villose pilei, typified by Trichaptum perrottetii (Lév.) Ryvarden. Since then it is generally acknowledged that Trichaptum is a cosmopolitan, well delimited genus embracing small but very distinct group of polypores, which show many unique features. Except for purplish colors and characteristic cystidia there are also distinctive generative hyphae with small clamps and with imperforate dolipore septa (Traquiar \& McKeen 1978), which indicates relationship to Hymenochaetales Oberw., not Polyporales Gäum. This was confirmed by molecular phylogeny that places species of Trichaptum in the so called Hymenochaetoid clade, close to Hyphodontia/Schizopora (Hibbet \& Binder 2002).

Eight species of Trichaptum occur in the temperate zone: T. abietinum (Dicks.) Ryvarden, $T$. fuscoviolaceum (Ehrenb.) Ryvarden, T. laricinum (P. Karst.) Ryvarden, T. subchartaceum (Murrill) Ryvarden (in North America, Zhou et al. 2016), Trichaptum polycystidiatum (Pilát) Y.C. Dai, Trichaptum perenne Y.C. Dai \& H.S. Yuan and Trichaptum montanum T. Hatt. in Asia (Dai et al. 2009, Dai 2012), and T. biforme (Fr.) Ryvarden, the last one being reportedly cosmopolitan, growing also in tropical regions. They belong to the most common wood-decaying fungi of great 
economic importance. All these species have rather similar spores and cystidia but macroscopic markers, especially juvenile pores size and shape can be used for reliable determination.

Subtropical and tropical regions of South America host more Trichaptum species which indicates possible determination problems, because species delimitation is also based mostly on macro-morphology (Ryvarden 2016). Determination supported by DNA-based phylogenetic analysis cannot be applied because few sequences are available in GenBank: two specimens of $T$. byssogenum (Jungh.) Ryvarden, both from East Asia, and two specimens of T. sector (Ehrenb.) Kreisel from Brazil (Apr 2017).

In the last few years, we have collected a sequenced many Trichaptum specimens in Texas, Florida, Caribbean Region and Costa Rica and encountered problems with species determination. Our aim is to use ITS region sequencing for improving taxonomy of Trichaptum occurring in tropical America.

\section{Materials \& Methods}

Trichaptum specimens were collected during 2005-2017 on various localities in the USA, US Virgins Islands, Puerto Rico, and Costa Rica; standard T. abietinum and T. fuscoviolaceum also in the Czech Republic, Europe. The specimens were dried and microscopically inspected in Melzer's reagent (IKI) and $5 \% \mathrm{KOH}$. Collected specimens are deposited in the herbarium of the first author, type specimens also in National Museum of the Czech Republic (PRM).

DNA isolation and PCR procedure follow Vlasák \& Kout (2011). The ITS region was amplified with primers ITS5 and ITS4 (White et al. 1990) and the sequences were aligned with Clustal W using very low values for gap penalty to accommodate long insertions in Trichaptum abietinum sequences: gap opening penalty was set at 4 and gap extension penalty was set at 0 . Proper alignment of conserved regions was manually checked. Maximum likelihood analyses were conducted in MEGA6 using the Tamura 3-parameter model with gamma distribution with 5 invariant sites, which was determined as the best-fit model with "Model testing for estimation of distances" option (Tamura et al. 2013).

\section{Results}

30 ITS rDNA region sequences of twelve Trichaptum species, six of which were sequenced for the first time, and also three sequences of Nigrofomes melanoporus (Mont.) Murrill were generated for this study. In the phylogenetic analysis, another 18 sequences were retrieved from GenBank. Clustal W program produced an alignment of 1335 characters, 350 of which were parsimony informative. In positions where T. fuscoviolaceum and T. abietinum specimens contain long inserts in ITS1 (Ko \& Jung 2002), the alignment produced up to $210 \mathrm{~b}$ long gaps in sequences of other species. Except for the rather structured T. abietinum/T. fuscoviolaceum clade (Ko \& Jung 2002), which is not our object of interest, phylogenetic analysis resolved the taxonomical structure of Trichaptum in a more or less expected way (Fig. 1). Sequences of clearly-defined species such as T. biforme, $T$. byssogenum, T. fumosoavellaneum (Romell) Rajchenb. \& Bianchin., $T$. fuscoviolaceum, T. laricinum, T. perrottettii and T. subchartaceum produced strongly supported terminal clades. T. byssogenum sequences from East Asia (type locality) are identical with those from America. USA collections of T. sector show sequences slightly different from Costa Rica and Brazil collections. The differences are small, however, and more collections analyzed by multigenic phylogeny are needed to decide, if more species are involved. Somewhat surprisingly, specimens of Nigrofomes melanoporus created a sister clade to T. laricinum, and through a deeper node they are related also to $T$. perrottettii, a type species of Trichaptum. We do not intend to make taxonomical conclusions on generic level based on single-gene sequence. It should be noted, however that Nigrofomes has the same blackish-violet colors as most Trichaptum species, similar skeletal hyphae, and also a kind of cystidia, even if very rarely occurring. On the other hand, distinct crust on pileus surface and lack of clamps on generative hyphae separate Nigrofomes from Trichaptum 
Specimens of three Trichaptum species which we were not able identify with described species, produced sequences that also make strongly supported terminal clades and are described below as new species.

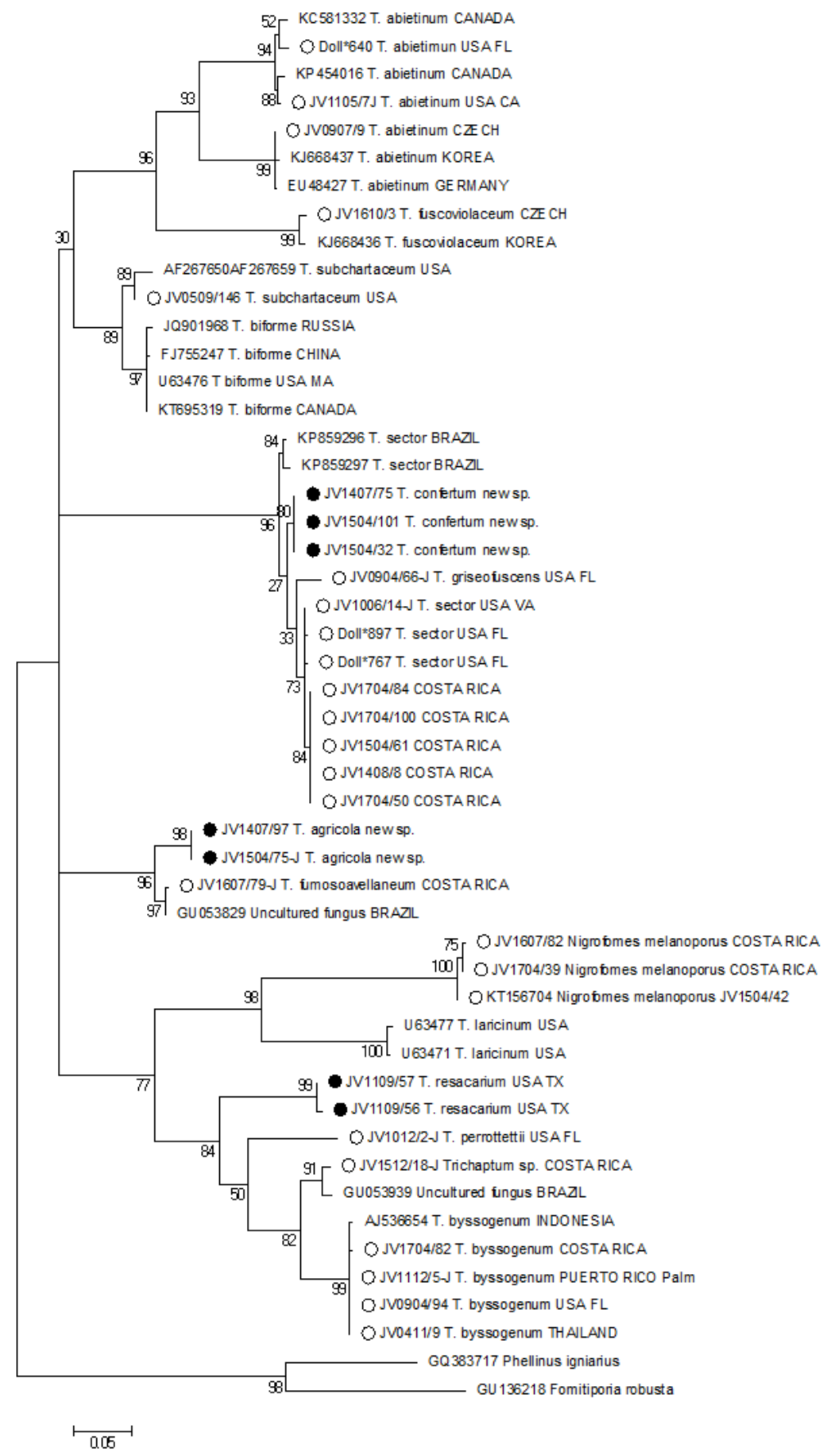

Figure 1 - Phylogenetic relationships of 45 Trichaptum and 3 Nigrofomes specimens inferred with ITS rDNA. Phellinus igniarius and Fomitiporia robusta were used to root the tree. Topology from maximum likelihood (ML) analysis. Support values along branches from ML bootstrap (500 replicates). The tree is drawn to scale, with branch lengths measured in the number of substitutions per site. Circles indicate sequences generated in this study, black circles specimens of new species. GenBank numbers indicate sequences retrieved from GenBank; two sequences marked as "Uncultured fungus" come from filter-collected spores - see Discussion.

Trichaptum agricola Vlasák \& Vlasák Jr., sp. nov.

Etymology - named for its resemblance to $C$. theobromae. 
Differs from other Trichaptum species by about $2 \mathrm{~cm}$ thick basidiocarps, lack of violet colors, large, isodiametric, entire pores 1-3 per $\mathrm{mm}$ and by ITS rDNA sequence. Thick-walled and apically encrusted cystidia abundantly present, basidiospores ellipsoid, thin-walled, IKI-, 4-5 $\times$ $2.5-3 \mu \mathrm{m}$.

Type - Costa Rica, Puntarenas Prov.: La Ensenada Lodge, hardwood prop, 22.IV.2015 Vlasák Jr. 1504/75-J (PRM 945505, JV, GenBank MF380995)

Basidiomes - Annual to biannual, sessile, broadly attached, up to $10 \times 5 \times 2 \mathrm{~cm}$, rarely with tube layer somewhat effused on the substrate below the pilei. Upper surface tomentose, velvety on touch, later glabrous, with age becoming warted or with irregular outgrows, azonate or sometimes slightly concentrically sulcate near the margin, light brown, later with a silvery shine, margin obtuse to sharp, concolorous. Pore surface brown, pores angular, 1-3 per mm, regular, or in parts somewhat radially elongated or labyrinthine, with moderately thin, entire dissepiment, context up
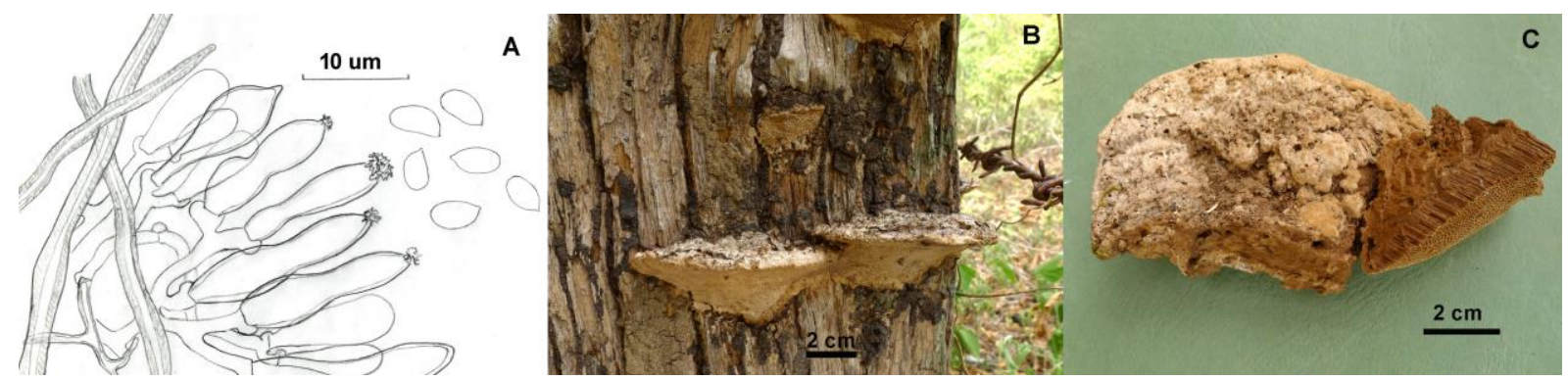

Figure 2 - A. Microscopical features of Trichaptum Agricola. B. spec. 1407/97 in situ. C. holotype in herbarium.

to $10 \mathrm{~mm}$ thick, tough, brown, with several distinct growth zones about $2 \mathrm{~mm}$ thick, indistinctly delimited towards the pilei cover; tube layer up to $10 \mathrm{~mm}$ thick, indistinctly stratified.

Hyphal system - Trimitic, generative hyphae hyaline, thin-walled, 2-3 $\mu \mathrm{m}$ in diam., with abundant, small clamps, skeletal hyphae brownish, thick-walled, 2-4 $\mu \mathrm{m}$ in diam., binding hyphae very rare, hyaline, 2-3 $\mu \mathrm{m}$, with short branches. Basidia clavate, 4-sterigmate, $12-15 \times 5-6 \mu \mathrm{m}$. Cystidia very abundant, 10-20 × 4-7 $\mu \mathrm{m}$, ventricose to fusoid, slightly thick-walled and apically encrusted. Basidiospores ellipsoid, hyaline, smooth, thin-walled, IKI-, 4-5 × 2.5-3 $\mu \mathrm{m}$.

Distribution - Collected in two dry farmland localities and in both cases the fungus was common on fence props. In one of these localities, it was found also in nearby woods on a dead stag.

Notes - Trichaptum agricola looks very much like Trametes gibbosa (Pers.) Fr., because of thick basidiocarps with uneven surface, but it is brown in all parts and has large, isodiametric pores. The violet colors, typical for Trichaptum, were not noted in our collections, which were however represented by rather old pilei.

Trichaptum confertum Vlasák \& Vlasák Jr., sp. nov.

Figs 3

MycoBank number: MB 821866

Etymology - Confertum (Lat.): indicating densely arranged pilei.

Distinguished by small, only $0.5-2 \mathrm{~cm}$ wide and $1 \mathrm{~mm}$ thick pilei, densely imbricate and rather dark, greyish-black with purplish to bluish tints when fresh. Pores and spores smaller than in similar species: pores 6-8 per mm, basidiospores 4-4.5 × 1.8-2.2 $\mu \mathrm{m}$.

Type - Costa Rica. Puntarenas Prov.: Monteverde, Santa Elena, Cerro Amigos Road, hardwood, 29.VII.2014 Vlasák 1407/75 (JV, PRM 945506, GenBank MF380988, MF380989).

Basidiomes - Annual, pileate, dimidiate to flabelliform, or broadly attached but mostly effused-reflexed, pilei 5-20 $\mathrm{mm}$ long and wide and only $1 \mathrm{~mm}$ thick, densely imbricate. Upper surface dark gray to black with purplish to bluish tints, fading to brown after drying, adpressed velutinate to tomentose, zonate, margin sharp and wavy, concolorous. Pore surface dark purplish when fresh, greyish brown after drying, pores angular, 6-8 per $\mathrm{mm}$, with thick, entire dissepiments, 
somewhat irregular or slightly lacerate in old specimens, context about $0.7 \mathrm{~mm}$ thick, tubes concolorous, up to $0.5 \mathrm{~mm}$ deep; context duplex, lower part dense and of the same dark brown color as the tube layer, upper layer white and cottony, only about $0.2 \mathrm{~mm}$ thick.
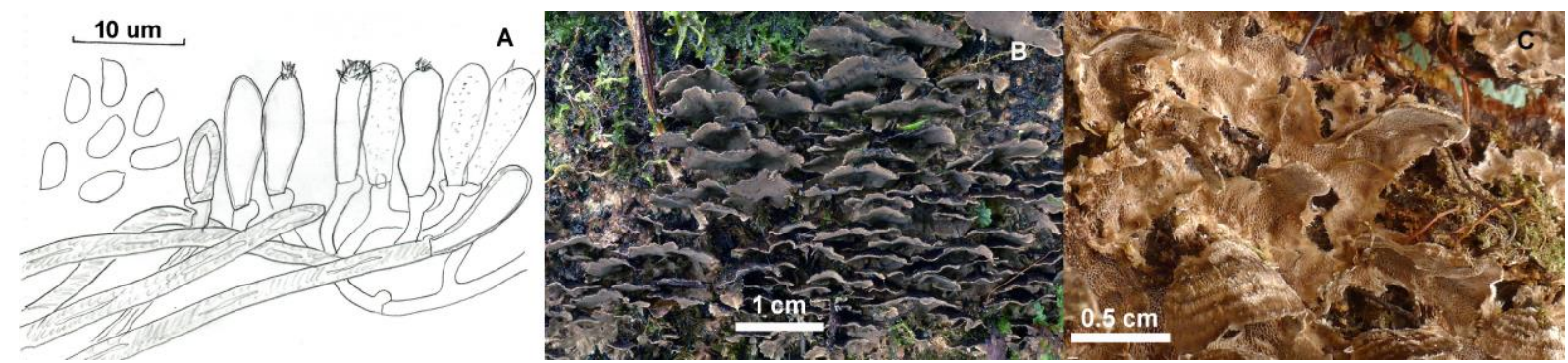

Figure 3 - A. Microscopical features of Trichaptum confertum. B. holotype in situ. C. in herbarium.

Hyphal system - Trimitic, generative hyphae hyaline, thin-walled, 2-3 $\mu \mathrm{m}$ in diam., with abundant, small clamps, skeletal hyphae brownish, thick-walled, mostly narrow, 2-3 $\mu \mathrm{m}$ in diam., with rounded ends, binding hyphae rare, but typically developed, 2-3 $\mu \mathrm{m}$, with many short branches. Basidia clavate, 4-sterigmate, 10-13 × 4-5 $\mu \mathrm{m}$. Cystidia 10-15 × 3-5 $\mu \mathrm{m}$, ventricose, thin- to slightly thick-walled and apically encrusted. Basidiospores ellipsoid, hyaline, smooth, thinwalled, IKI-, 4-4.5 (5) $\times 1.8-2.2 \mu \mathrm{m}$, often collapsed to rugged ellipsoid structures.

Distribution - Collected in two localities and noted also in other places in montane cloud forests, always covering large areas on dead logs. Seems to be quite common.

Notes - The species is closely related to T. sector but differs by smaller pilei, pores and spores and by bluish or purplish colors when fresh. T. sector never develops purplish tinge and the pilei are up to $5 \mathrm{~cm}$ wide, with pores $3-5$ per $\mathrm{mm}$ and spores subcylindrical, $6-7 \mu \mathrm{m}$ long.

Trichaptum resacarium Vlasák \& Vlasák Jr., sp. nov.

Figs 4

MycoBank number: MB 821866

Etymology - Indicating growth around Rio Grande old channels called resaca (Spanish).

Similar to T. byssogenum but distinguished by poorly developed pilei, dark hymenial surface, blackish hairs on pileal surface making a loose net, small spores 3.5-4 $42 \mu \mathrm{m}$, neckige cystidia and heavily incrusted hyphal ends. ITS RNA sequence is also different.

Type - USA. Texas: Cameron County, Pharr, hardwood, 27.IX.2011 Vlasák 1109/57 (JV, PRM 945510, GenBank MF381017, MF381018)

Basidiomes - Annual, resupinate, rarely with small reflexed pilei $0.5-2 \times 0.5-1 \mathrm{~cm}$, upper surface greyish tomentose to hispid and radially striate with coarse, blackish hairs making a prominent, loose net, margin sharp, concolorous. Pore surface dark fuliginous with purplish tint, pores angular, (0.5)1-2 per mm, with rather thick dissepiments, irregular or somewhat irpicoid in old specimens, sometimes developed as flat teeth $1-2 \times 0.4 \times 4 \mathrm{~mm}$, tubes concolorous, up to $4 \mathrm{~mm}$ deep; context about $1 \mathrm{~mm}$ thick, duplex, lower part dense and of the same dark brown color as the tube layer, upper layer cottony, with blackish hairs.

Hyphal system - Dimitic, generative hyphae hyaline, thin-walled, 2-3 $\mu \mathrm{m}$ in diam., with abundant, small clamps, skeletal hyphae brownish, thick-walled, 2-3 $\mu \mathrm{m}$ in diam., with rounded ends, which in hymenium or on pore-edges often covered with a layer of crystals reminding of Skeletocutis incrustation. Basidia clavate, 4-sterigmate, 12-15 $\times 5-6 \mu \mathrm{m}$. Cystidia very abundant, fusoid, $15-30 \times 3-5 \mu \mathrm{m}$, thin- to slightly thick-walled, mostly with long narrow necks up to 5-10 $\times$ $1.5 \mu \mathrm{m}$ apically encrusted or smooth, light brown., the hymenial layer very dark under microscope because of abundance of brownish cystidia. Basidiospores sparse, ellipsoid, hyaline, smooth, thinwalled, IKI-, 3.5-4 × $2 \mu \mathrm{m}$.

Distribution - Collected twice but noted several times around Rio Grande dead channels on hardwood twigs lying on the ground. 

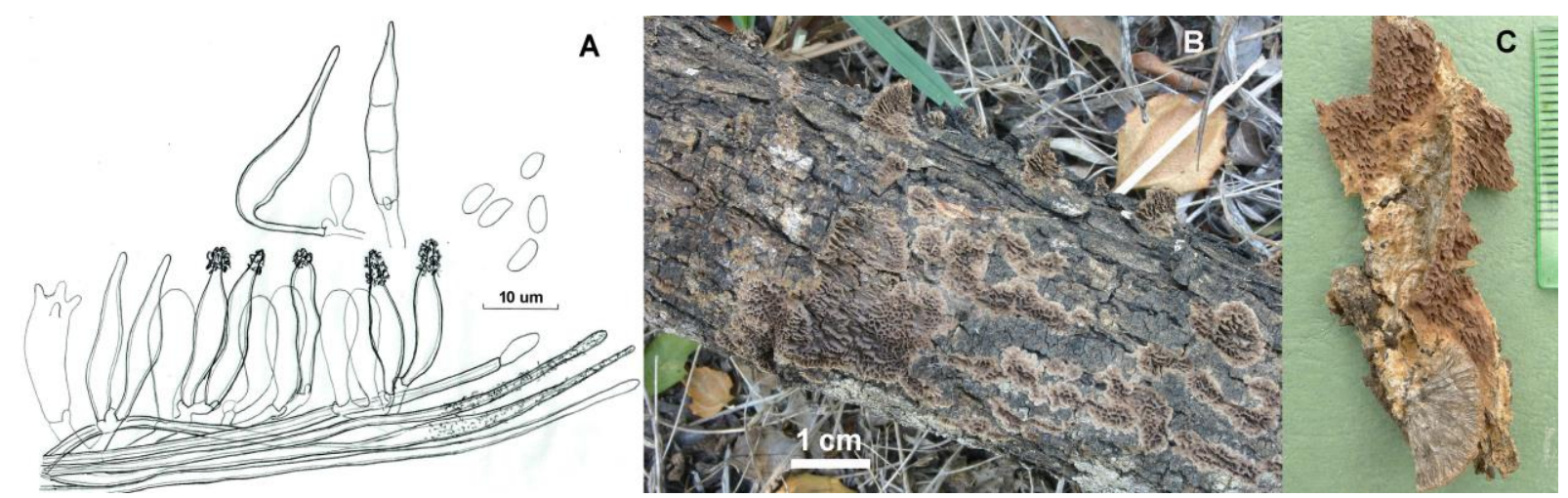

Figure 4 - A. Microscopical features of Trichaptum resacarium. B. holotype in situ. C. spec. 1109/56 herbarium.

Notes - Trichaptum cladotrichum (Berk. \& M.A. Curtis 1868) Murrill 1904 collected in Cuba, which was later synonymized with T. byssogenum (Ryvarden 1984), differs in having pilei 5-7 cm broad, with "spongy strigose coating without prominent fibers". Also, dark hymenial surface and small spores are not mentioned in the original or later descriptions.

Notes on some other species from tropical America:

Trichaptum biforme (Fr.) Ryvarden

T. biforme is reported as the only cosmopolitan Trichaptum species (Ryvarden 2016). It is very common in the eastern USA, Europe and Asia and it is similar to other Trichaptum species in that region, showing mostly flabelliform, thin pilei with greyish, zonate surface and violaceous, angular, later irpicoid pores. It should be noted that we were not able to find it in Central America though we have looked for it. There are about 20 sequences of T. biforme in GenBank but none of them comes from tropical regions.

Trichaptum byssogenum (Jungh.) Ryvarden

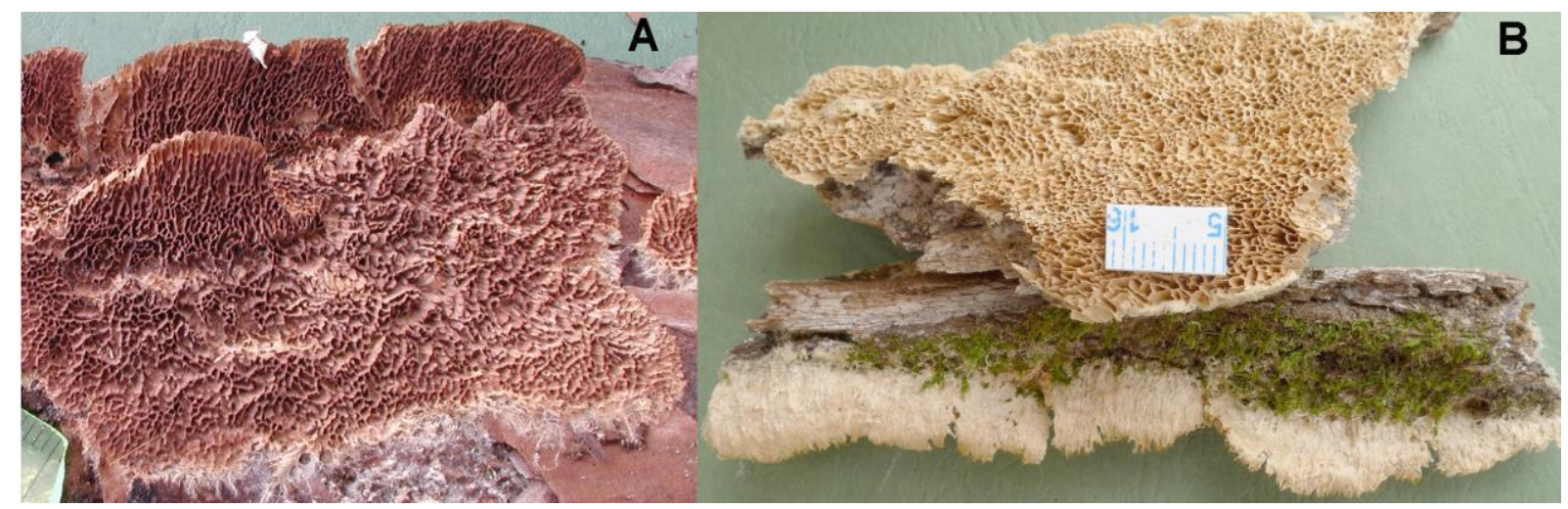

Figure 5 - A. Trichaptum byssogenum spec. 0904/95. B. Trichaptum sp. spec. 1512/18-J.

Effused-reflexed basidiomes show characteristic, coarsely-strigose upper surface, greyish tan to whitish, and large angular pores 1-2 per mm, purplish when fresh, dull purplish brown on drying, which become lacerate and partly lamellate towards the margin (Fig. 5A). The basidiospores are cylindric, 5.5-8 × 2-2.5 $\square \mathrm{m}$ (Ryvarden 2016), in our measurements somewhat broader, subcylindric, 5.5-7 $\times 2.2-3 \square \mathrm{m}$. T. byssogenum was described from Java but it is a pantropical species. It is quite common on pines in Florida, but rather rare on hardwoods in Costa Rica and the Caribbean Region.

\section{Trichaptum sp. 1512/18-J}

This species is similar to $T$. byssogenum but can be distinguished by extremely thin or almost missing context, lack of purplish colors on pores, which are also somewhat larger, $0.5-2$ per mm, 
isodiametric and without tendency to become lamellate towards the margin (Fig. 5B). Spores are broadly ellipsoid, $6.5-8 \times 3.3-4 \mu \mathrm{m}$, which is unique in Trichaptum. The ITS sequence is related to T. byssogenum, but distinctly different. We have found this species only once in Costa Rica; the same sequence, however, is present several times in GenBank as "Uncultured fungus"- see Discussion. Ryvarden and Johansen (1980) show a picture of Trametes versatilis Berk 1842 features (synonym of Trichaptum byssogenum, collected in the USA) where the spores perfectly correspond to our Trichaptum sp. spores. We have not seen the type deposited in Kew and so we cannot decide now if our Trichaptum sp. is identical with Trametes versatilis or not.

Trichaptum fumosoavellaneum (Romell) Raichenb.

Largest of all Trichaptum species, showing massive pilei up to $40 \mathrm{~cm}$ in diam. and $10 \mathrm{~cm}$ thick (Fig. 6A). Thick context, isodiametric, entire pores, similar spores and ITS sequence indicate relationship with $T$. agricola described above. Nevertheless, except for its size, $T$. fumosoavellaneum is distinguished by smaller pores 3-4 per $\mathrm{mm}$, and usually distinct violet colors.

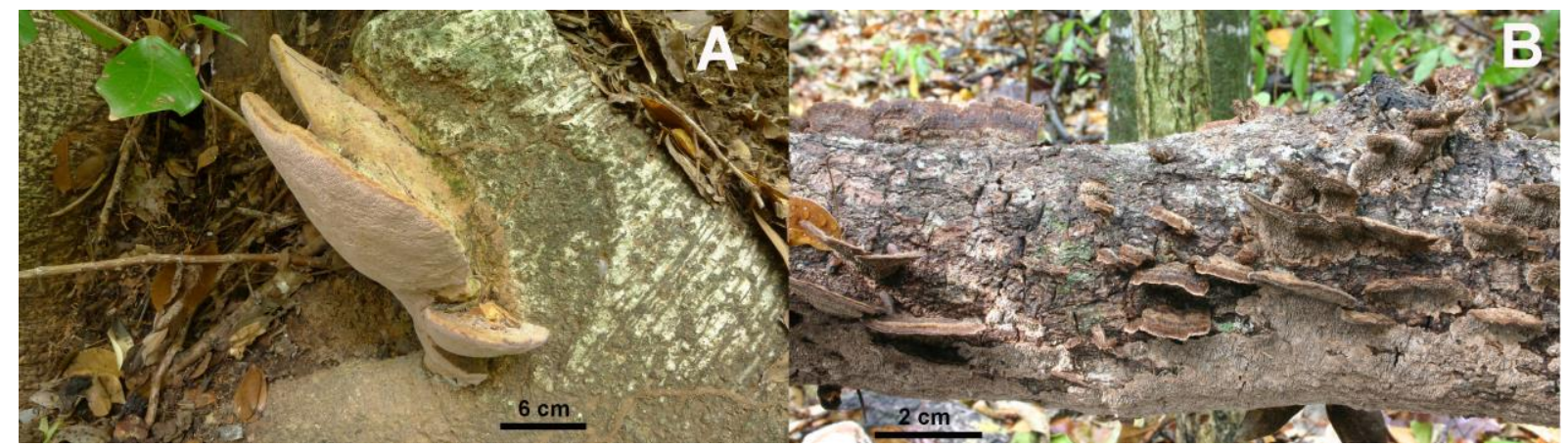

Figure 6 - A. Trichaptum fumosoavellaneum spec. 1607/79-J. B. T. griseofuscens 0904/66-J, both in situ.

Trichaptum griseofuscens (Mont.) Ryvarden \& Iturr.

This species is similar and related to $T$. sector but with a hydnoid hymenophore from the very beginning (Fig. 6B), more brownish pilei, and narrower spores.

\section{Trichaptum perrottetii (Lév.) Ryvarden}

The basidiocarps are pileate, broadly-attached and not decurrent on substrate, 5-10 cm wide and up to $2 \mathrm{~cm}$ thick, with unique, $0.5 \mathrm{~cm}$ thick, blackish mat of entangled strigose and forked hairs on pileal surface, reminding of Hexagonia hydnoides pileal cover. Pores violet, on drying becoming brown, 2-3 per $\mathrm{mm}$, later with incised dissepiments. Unmistakable species but rather rare, according to our experience.

\section{Trichaptum sector (Ehrenb.) Kreisel}

T. sector is a common species of south-eastern USA, easily recognized in the field because of subshiny, white to pale buff pilei and dark greyish pore surface without a purplish tinge. In Costa Rica, however, a different type is present which shows some bluish tints on pores when fresh, somewhat shorter spores and slightly different sequence. It is widely distributed and common in both mountain and lowland wet tropical forests. Two sequences of $T$. sector from Brazil in GenBank may represent still another species, even if closely related. It is possible that $T$. sector in classical sense represents a complex of closely related species that should be studied by more sophisticated methods. Unfortunately, we have not inspected any collection from Brazil (type locality of $T$. sector).

\section{Discussion}

Trichaptum is one of few polypore genera where microscopical routine is of little use for species determination. Macroscopic features are much more significant but sometimes too variable 
and not sufficiently discriminating. In such cases, sequence-based phylogeny is of the most importance. ITS sequences provide a robust tool for the discrimination of Trichaptum species. For instance, the rather similar T. biforme and T. sector differ in 54 positions of ITS1 and in 62 positions of ITS2. In contrasts, in the case of many other polypores, e.g. Antrodia P. Karst., similar species may differ only in 3-4 positions (Spirin et al. 2016, 2017). Analysis of a broad set of newly prepared sequences enabled us to confirm three new species described above and also to open unlooked-for issues of Trametes versatilis and Trichaptum sector identity and of Nigrofomes vs. Trichaptum relationship. These questions aim however over the scope of our paper and would require multigenic phylogenetic analyses.

Because our Trichaptum sampling did not cover South America we have analyzed aerosol sequencing results of Frohlich-Nowoiski et al. (2012) that originated from sampling performed in Rondonia, Brazil, in the south-western part of the Amazon Basin. In this method, fungal spores are collected for several days on glass fiber filters, bulk DNA is isolated and amplified, cloned, and clones are then individually sequenced. 15 sequences published by Frohlich-Nowoiski et al. (2012) represent according to our analysis Trichaptum species and all can be assigned to species studied by us. Six (D01, D08, F06, F07, H09, and H10) belong to T. byssogenum, another six (D03, D05, D09, E09, G11 and F03-shown in Fig. 1) correspond with Trichaptum sp. 1512/18-J (Trametes versatilis?), one (E11, Fig 1) is T. fumosoavellaneum and two (E05 and E06) are surprisingly $T$. abietinum - a species which we would not expect in South America. On the other hand, T. perrottettii, $T$. sector, and $T$. biforme are not represented, as well as our three newly described species.

Ryvarden (2016) lists 12 Trichaptum species in South America. Of them, however, T. sprucei belongs to Phaeodaedalea Lloyd and T. durum (Jungh.) Corner to Nigroporus Murrill, according to "Index fungorum". Eight other species which we have studied are treated above. T. strigosum Corner seems to be restricted to Amazonia and we have not seen it as well as three other species that were described relatively recently from type localities only (T. bulbocystidiatum Ryvarden, $T$. deviatum Ryvarden and $T$. variabilis Ryvarden and Iturriaga). To get more current overview, we have adopted Trichaptum key of Ryvarden (2016) for the changes suggested above and inclusion of newly described species.

\section{Specimens examined}

Nigrofomes melanoporus. Costa Rica. Puntarenas Prov.: Piedras Blancas, hardwood, 20.IV.2015 Vlasák 1504/38, 1504/42 (JV, GenBank KT156704), Golfito, Playa Nicuesa, hardwood, 18.IV.2017 Vlasák 1704/39, 1704/47 (JV, GenBank MF381028). Alajuela Prov.: Bijagua, hardwood, 28.VII.2016, Vlasák 1607/82 (JV, GenBank MF381027).

Trichaptum abietinum. Czech Republic. Hluboka: Karvanice PR, Picea abies, 25.VII.2009 Vlasák 0907/9 (JV, GenBank MF381023). USA. California: Purissima Creek, Half Moon Bay, douglas fir, V.2011 Vlasák Jr. 1105/7-J (JV, GenBank MF381024, MF381025). Florida: Lakewood Ranch, Pinus, 3.II.2016 Dollinger 640 (JV, GenBank MF381922)

Trichaptum agricola. Costa Rica. Guanacaste Prov.: Ahogados, hardwood fence prop, 31.VII. 2014 Vlasák 1407/97, 1407/98 (JV, GenBank MF380993, MF380994), hardwood dead stag Vlasák $1407 / 99$ (JV), Puntarenas Prov: La Ensenada Lodge, hardwood, 22.IV.2015 Vlasák Jr. 1504/75-J (JV, PRM 945505, GenBank MF380995).

Trichaptum byssogenum. Costa Rica. Puntarenas Prov.: Dominical, Hacienda Barú, hardwood, 21.IV.2017 Vlasák 1704/82 (JV, GenBank MF381014). Puerto Rico. San Juan, palm tree, XII.2011 Vlasák Jr. 1112/5-J (JV, GenBank MF381013). Thailand. Thaleban Nat. Park, hardwood, 25.XI.2004 J.Kout 0411/9 (JV, GenBank MF381015, MF381016). USA. Florida: Everglades, Long Pine Key, Pinus, 22.IV.2009 Vlasák 0904/94 (JV, GenBank MF381012), Sarasota, Pinus, 
30.XII.2015 Dollinger 632 (JV). US Virgin Islands: St. John, hardwood, 4.IX.2004 Vlasák Jr. $0409 / 22-J(\mathrm{JV})$.

Trichaptum confertum. Costa Rica. Puntarenas Prov.: Monteverde, Santa Elena, Cerro Amigos Road, hardwood, 29.VII.2014 Vlasák 1407/75 (JV, PRM 945506, GenBank MF380988, MF380989), El Establo Hotel trails, hardwood, 24.IV.2015 Vlasák 1504/101 (JV, GenBank MF380992), Golfito, Playa Cacao, hardwood, 19.IV.2015 Vlasák 1504/32 (JV, GenBank MF380990, MF380991).

Trichaptum fumosoavellaneum. Costa Rica. Guanacaste Prov.: Lomas Bardubal, hardwood, 27.VII.2016 Vlasák Jr. 1607/79-J (JV, GenBank MF381021).

Trichaptum fuscoviolaceum. Czech Republic. Hluboka: Bezdrev, Jaderny, Pinus sylvatica, 30.X.2016 Vlasák 1610/3 (JV, GenBank MF381026).

Trichaptum griseofuscens. USA. Florida: Key Largo, John Pennekamp Coral Reefs State Park, hardwood, 21.IV.2009 Vlasák Jr. 0904/66-J (JV, GenBank MF381009).

Trichaptum perrottettii. USA. Florida: Long Key Natural Area, SW 130th ave, hardwood, XII.2010 Vlasák Jr. 1012/2-J (JV, GenBank MF381011).

Trichaptum resacarium. USA. Texas: Cameron County, Pharr, hardwood, 27.IX.2011 Vlasák Jr. 1109/57 (JV, PRM 945510, GenBank MF381017, MF381018), Vlasák 1109/56 (JV, GenBank MF381019, MF381020).

Trichaptum sector. USA. Virginia: Virginia Beach, hardwood, VI.2010 Vlasák Jr. 1006/14-J (JV, GenBank MF380997). Florida: Royal Palm St. Park, Swietenia mahagoni, 29.VIII.2010 Vlasák Jr. 1008/70-J (JV); Sarasota, hardwood, 8.V.2016 Dollinger 767 (JV, GenBank MF380999); Parrish, Rye Preserve, hardwood, 16.VIII.2016 Dollinger 897 (JV, GenBank MF380998). Costa Rica. Guanacaste Prov.: Rincon de la Vieja, hardwood, 1.VIII.2014 Vlasák 1408/8 (JV, GenBank MF381000, MF381001). Puntarenas Prov.: Tarcoles, Laguna Meandrica, hardwood, 22.IV.2015 Vlasák 1504/61 (JV, GenBank MF381002, MF381003); Golfito, Playa Nicuesa, hardwood, 18.IV.2017 Vlasák 1704/50 (JV, GenBank MF381004); Dominical, Hacienda Barú, hardwood, 21.IV.2017 Vlasák 1704/84 (JV, GenBank MF381005, MF381006); Tarcoles, Carara Nat. Park, hardwood, 22.IV.2017 Vlasák 1704/100 (JV, GenBank MF381007, MF381008)

Trichaptum sp. Costa Rica. Guanacaste Prov.: Santa Cruz, hardwood, 28.XII. 2015 Vlasák Jr. 1512/18-J (JV, PRM 945507, GenBank MF380996).

Trichaptum subchartaceum. USA. New York: Adirondack Park, Fish Creek Pond, Populus sp., 18.IX.2005 Vlasák 0509/146 (JV, GenBank MF381010

1. Basidiocarps pileate

Key to South-American Trichaptum species

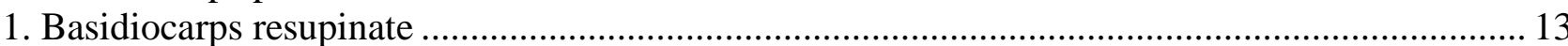

2. Pilei glabrous to adpressed tomentose mixed with glabrous zones ........................................... 3

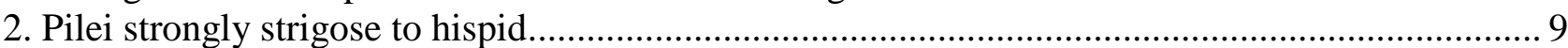

3. Hymenophore distinctly hydnoid ............................................................. griseofuscens

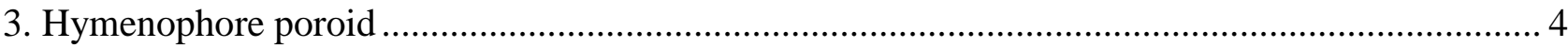

4. Basidiocarps $<3 \mathrm{~mm}$ thick, flexible, often in clusters, pileal surface velutinate to hirsute ........... 5

4. Basidiocarps $>10 \mathrm{~mm}$ thick, dense and hard, usually single, pileal surface glabrous .................... 7

5. Pore surface grey to black, pores entire, upper surface often grey to whitish T. sector 
5. Pore surface with violet tinge when fresh, fading to pale or deep brown

6. Upper surface light grey to deep beige, pore surface fading to beige, pores $3-5$ per $\mathrm{mm}$, later often lacerate or irpicoid

T. biforme

6. Upper surface blackish-grey, pore surface fading dark grey, pores 6-8 per mm, regular.

T. confertum

7. Pores irregular at least in parts, pore surface split with age, basidiocarp brown.

T. variabilis

7. Pores regular and round, pore surface even, basidiocarps greyish to clay colored 8

8. Pores 3-4 per mm, basidiocarps clay colored or brown with purplish tinge, up to $14 \mathrm{~cm}$ thick in massive specimens

T. fumosoavellaneum

8. Pores 1-3 per mm, basidiocarps brown and without purplish tints, up to $3 \mathrm{~cm}$ thick..... T. agricola

9. Pilei with a dense, $5 \mathrm{~mm}$ thick mat of dark brown strigose to hispid hairs, basidiocarps sessile......

T. perrottetii

9. Pilei with light gray to whitish hairs, basidiocarps resupinate, effused-reflexed or sessile 10

10. Spores $>3.3 \mu \mathrm{m}$ in width, pore surface without purplish tinge, pores isodiametric

Trichaptum sp. 1512/18-J

10. Spores $<3.3 \mu \mathrm{m}$ in width, pores with violet tinge when fresh, radially elongated 11

11. Pores $1-2$ per $\mathrm{mm}$ 12

11. Pores $2-4$ per mm, spores ellipsoid, $4.5-6 \times 2.5-3 \mu \mathrm{m}$ T. strigosum

12. Spores cylindrical $5.5-8 \times 2-2.5 \mu \mathrm{m}$, pore surface purplish or purplish brown ..... T. byssogenum

12. Spores ellipsoid 3.5-4 $\times 2 \mu \mathrm{m}$, pore surface dark fuliginous with purplish tint T. resacarium

13. Bulbous cystidia present, pores $2-4$ per $\mathrm{mm}$ T. bulbocystidiatum

13. Bulbous cystidia absent, pores 5-7 per $\mathrm{mm}$ T. deviatum

\section{Acknowledgements}

Neil Dollinger (USA, Florida) kindly provided us with specimens of Trichaptum abietinum, T. byssogenum and T. sector from Florida. The research of J. Vlasák was funded by the Academy of Science of the Czech Republic institutional support RVO: 60077344.

\section{References}

Dai YC. 2012 - Polypore diversity in China with an annotated checklist of Chinese polypores. Mycoscience 53, 49-80.

Dai YC, Cui BK, Yuan HS. 2009 - Trichaptum (Basidiomycota, Hymenochaetales) from China with a description of three new species. Mycological Progress 8, 281-287.

Donk MA. 1933 - Revision de Niederlandischen Homobasidiomycetes. Aphylophoraceae II. Meded. Bot. Mus. Herb. Rijksuniv. Utrecht 9, 168.

Frohlich-Nowoisky J, Burrows SM, Xie T, Engling G. et al. 2012 - Biogeography in the air: fungal diversity over land and oceans. Biogeosciences 9, 1125-1136. doi:10.5194/bg-9-1125-2012

Gilbertson RL, Ryvarden L. 1987 - North American polypores 2, pp. 434-885. Fungiflora Oslo.

Hibbett DS, Binder M. 2002 - Evolution of complex fruitingbody morphologies in homobasidiomycetes. Proc R Soc Lond B 269, 1963-1969. doi:10.1098/rspb.2002.2123

Ko KS, Jung HS. 2002 - Three nonorthologous ITS1 types are present in a polypore fungus Trichaptum abietinum. - Molecular Phylogenetics and Evolution 23, 112-122.

Pilát A. 1936-42 - Polyporaceae. In: Kavina K., Pilat A., eds., Atlas des Champignons de 1'Europe, Vol.3, pp. 1-624, Praha.

Ryvarden L. 1984 - Type studies in the Polyporaceae 16. Species described by J.M. Berkeley either alone or with other mycologists from 1856 to 1886. Mycotaxon 20, 329-363.

Ryvarden L. 2016 - Neotropical polypores Part 3, Polyporaceae, Obba-Wrightoporia, p. 562, Fungiflora Oslo.

Ryvarden L, Johansen I. 1980 - A preliminary polypore flora of East Africa, pp. 1-636, Fungiflora Oslo. 
Spirin V, Vlasák J, Rivoire B, Kotiranta H, Miettinen O. 2016 - Hidden diversity in the Antrodia malicola group (Polyporales, Basidiomycota) - Mycol. Progress 15, 51-63.

Spirin V, Vlasák J, Miettinen O. 2017 - Studies in Antrodia serialis group (Polyporales, Basidiomycota). - Mycologia 109, 217-230.

Tamura K, Stecher G, Peterson D, Filipski A, Kumar S. 2013 - MEGA 6: Molecular Evolutionary Genetics Analysis version 6.0. Mol. Biol. Evol. 30, 2725-2729. http://dx.doi.org/10.1093/molbev/mst197

Traquair JV, McKeen WE. 1978 - Ultrastructure of the dolipore septum in Hischioporus pergamenus (Polyporaceae). Can. J. Microbiol. 24, 67-771.

Vlasák J, Kout J. 2011 - Tropical Trametes lactinea is widely distributed in the eastern USA. Mycotaxon 115, 271-279. http://dx.doi.org/10.5248/115.271

White TJ, Bruns T, Lee S, Taylor J. 1990 - Amplification and direct sequencing of fungal ribosomal RNA genes for phylogenetics. 315-322, in: MA Innis et al. (eds). PCR Protocols: a guide to methods and applications. San Diego, Academic Press.

Zhou LW, Nakasone KK, Burdsall Jr. HH, Ginns J. et al. 2016 - Polypore diversity in North America with an annotated checklist. Mycological Progress 15, 771-790. 